\title{
Direct Democracy and Organized Interests: Examining the Existence of a Participation Gap among Groups
}

\section{Robert Alexander}

Scholars have devoted increased attention to the role of interest groups in direct democracy campaigns over the past few years. This study seeks to add to this literature by analyzing data drawn from a mail survey of over 400 organized interests in three states. In particular, I examine how and to what extent organized interests utilize tools of direct democracy. Among sample groups, I find that (1) Most groups do something relative to direct democracy; (2) Group activity varies significantly across states; (3) A group's overall activity varies considerably relative to their involvement with direct democracy; and (4) Little support exists supporting the notion that economic or business groups are more apt to participate in direct democracy than are other types of groups. In short, I find little evidence of a participation gap among different types of groups in the states relative to the practice of direct democracy. The variation in participation that does occur appears to be most closely related to a group's age and the existence of a PAC.

The past decade has witnessed a renewed interest in understanding direct democracy. As the number of ballot measures in the states has climbed, political scientists have been increasingly attentive to direct democracy (see, for example, Bowler and Donovan 1998, 2002; Bowler, Donovan and Tolbert 1998; Gerber 2004; Smith and Tolbert 2001; Tolbert, Grummel, and Smith 2001). In a similar vein, scholars of organized interests have made great strides in understanding the role of organized interests in American politics. According to Baumgartner and Leech $(1998,5)$, “. . . a resurgence has occurred in the study of interest groups, transforming the topic from one that was theory-rich but data-poor to one that is now rich on both counts."

A natural confluence between these streams of research has occurred as scholars have noted the ubiquity of interest groups in ballot campaigns (see, for example, Boehmke 2002; Broder 2000; Ellis 2002; Gerber 1999; Schrag 1998; and Stratmann 2006). A great deal of controversy exists as to the benefits or pitfalls of both direct democracy and interest groups in American politics. Proponents of direct democracy assert that it promotes open educated discourse, puts decision-making in the hands of the citizenry, and acts as a check on the power of government. Detractors conclude that it is a tool

This paper could not have been possible without the generous research assistance of Anthony Nownes. His help with the data collection and his many comments on drafts of this paper were extremely helpful.

ROBERT ALEXANDER is associate professor of political science at Ohio Northern University.

The American Review of Politics, Vol. 27, Winter, 2006: 345-365

(C)2006 The American Review of Politics 
best used by the wealthy. Opponents further claim that well-funded interest groups dominate the process and cloud, rather than inform the judgments of voters (Schrag 1998).

This study attempts to contribute to the growing literature on organized interests and direct democracy. Drawing upon data from a survey of over 400 organized interests in three states, I explore the nature and extent of group involvement in direct democracy campaigns. In particular, I examine whether a "participation gap" exists among groups when it comes to the practice of direct democracy. I am most interested in assessing how a group's resources and the type of group affect participation in direct democracy campaigns. Toward this end, this paper investigates what groups are doing relative to direct democracy, why groups choose to participate in ballot contests, and what differences exist between users and non-users of direct democracy.

\section{Organizational Resources and the Practice of Direct Democracy}

A great body of research has emerged documenting a seemingly endless repertoire of techniques groups utilize. Schlozman and Tierney's (1986) observations regarding the increase in grassroots lobbying techniques coupled with Kollman's (1998) analysis of the expansion of outside lobbying among interest groups point to the adaptability of groups within the political process. As communications techniques have evolved, many groups have been quick to adapt to these new media to convey their messages to the masses. Baumgartner and Leech (1998) document research devoted to understanding the usage of various lobbying techniques by interest groups.

Toward this end, a growing literature has examined how direct democracy figures into the lobbying repertoire of organized interests. The ballot process provides yet another avenue for groups to participate in the political process. While important advances have been made in our understanding of group involvement in these campaigns, debate persists as to which groups are best equipped to participate in direct democracy, what groups seek to achieve through direct democracy, and whether differences exist among users and non-users of direct democracy.

Richard Ellis $(2002,109)$ states that "the initiative process does not offer a respite from interest group politics but rather a new venue in which most of the same old interest groups contest for power." He goes on to note that some groups may be advantaged by the process relative to their influence in traditional venues. He makes the point that money alone does not distinguish those who are advantaged through direct democracy and those who are not. Similarly, Boehmke (2002) suggests that one must take into account the indirect effects of the initiative process such as the incentive to 
mobilize for potential groups. He finds a greater number and diversity of interests exists in initiative states versus non-initiative states. He argues that direct democracy can have the effect of drawing more interests into the political fray and thereby enhancing the democratic process. Thus, studying money spent by interest groups in ballot campaigns does not provide a complete picture of initiative politics.

Ernst (2001) suggests that fears regarding the capture of the initiative process by special interests are overstated. Taking into account the organizational and monetary resources of groups, he finds that "narrow-material interests historically and currently operate at a severe electoral disadvantage in initiative politics" (Ernst 2001, 26). Nevertheless, a great deal of research indicates that campaign spending is positively related to the defeat of initiatives and the preservation of the status quo (Gerber 1999; Lowenstein 1982; Magelby 1984). Similarly, David Broder's (2000) descriptive account of initiative politics finds that money often plays a significant role in accomplishing the goals of wealthy interest groups in ballot campaigns.

Elizabeth Gerber's (1999) examination of the "the populist paradox" provides an important contribution to our understanding of group involvement in initiative politics. Gerber classifies groups according to their ability to acquire the resources necessary to wage successful ballot campaigns. To affect the outcome of direct democratic elections, she argues that organized interests must overcome institutional and electoral barriers. Her theory argues that citizen (or public interest) groups are best able to mobilize personnel resources that can be utilized during ballot campaigns, while economic groups are better suited to mobilize monetary resources. Gerber posits that few organized interests will have large amounts of both personnel and monetary resources. Any organized interest that could mobilize both people and money, would be quite formidable in the direct democracy arena.

In the end, Gerber finds that economic groups have a difficult time achieving direct modifying influence in direct democracy campaigns, but are successful in maintaining the status quo. She also finds that while initiatives undertaken by citizen groups pass at higher rates than those undertaken by economic groups, the lack of monetary resources available to many citizen groups prohibits them from going to the ballot frequently. However, her findings do not settle the question of popular versus elite representation in direct democracy.

Recently, Stratmann (2006) suggests that the confusion over the influence of money can be attributed to the strategic spending of groups in ballot contests. The likelihood of winning or losing affects the amount of money groups are willing to spend in campaigns. Moreover, the money spent during the qualification phase does little to influence the outcome of the contest. Consequently, understanding the significance of money becomes difficult to 
achieve. Stratmann argues that studies seeking to understand the effect of money in ballot campaigns should examine the most notable way voters are exposed and therefore influenced in ballot campaigns - television advertising. He finds that advertising dollars spent in the opposition of initiatives have no more effect than those spent in favor of an initiative. In sum, his findings suggest that scholars should recognize that groups' campaign spending on television advertising is crucial to the outcomes of ballot contests.

\section{Research Questions}

It is clear that scholars have taken notice of the role of groups in ballot campaigns. However as Boehmke $(2002,828)$ notes: "Little work has been done...on the role of political institutions in mobilization and formation decisions, but recent research suggests that interest group formation is influenced by the opportunities that these institutions create." The presence of direct democracy affects many of the institutions political scientists study. By analyzing group activity relative to direct democracy, this project seeks to contribute to the debate over interest group involvement in ballot campaigns. In particular, this study attempts to discern whether or not a participation gap exists among groups in initiative states. The disproportionate usage of direct democracy among groups is a frequent subject of debate among scholars. Whether a participation gap exists between the economic haves and have-nots is an important question whose answer has real policy consequences given the popularity of ballot-box lawmaking.

Although Gerber's (1999) work contributed a great deal to our understanding of group involvement with direct democracy, the size of her sample and her conceptualization of citizen groups mark important limitations in her study. She sought to identify initiative users by sampling from the population of interests that had contributed money to a ballot campaign over the course of several years. While such a design has its advantages, several problems exist. Although an adequate response rate of 26 percent was achieved, Gerber had an N of only 156 groups. This led her to combine responses among her four initiative user states as well as collapse certain types of groups together in order to have an adequate number of cases to compare (Gerber 1999, 78-9). Hence, I contend that collecting a larger sample and drawing data from a different population is warranted. Expanding the number of cases among a different population of groups should allow for greater confidence as we seek to distinguish whether some groups are better able to participate in direct democracy campaigns.

As noted above, Gerber often collapses labor unions (occupational groups) and citizen groups into one category. Her justification that each 
would be more likely to draw upon personnel resources is debatable given that labor unions often have vast sums of money as a result of compulsory dues. The characteristics and the motivation among unions and citizen groups can be and often are quite different. Likewise, Kollman (1998) finds that labor unions account for a great deal of activity in outside lobbying campaigns. As I conceptualize campaigning in direct democracy as a form of outside lobbying, separating citizen group activity from labor union activity is warranted. Ellis $(2002,102)$ pointedly suggests that "labor unions have figured prominently in a number of recent initiative campaigns." If this is indeed the case, collapsing citizen groups with labor unions would be problematic. Thus, this study seeks to rectify these concerns through a mail survey with a broader sample aimed at examining group usage of direct democracy.

This project asks three broad questions: (1) What are groups doing relative to direct democracy?; (2) Why do groups participate through direct democracy?; and (3) What differences exist between users and non-users of direct democracy? The first two questions seek to describe group involvement with direct democracy. Clearly these questions require the kind of thick description surveys are able to produce. As for the first question, although scholars have found that a number of groups report being active direct democracy users, few have systematically examined how groups use direct democracy. I attempt to fill this void by investigating the ways that groups seek to engage in direct democracy campaigns. In particular, this study builds upon the findings of Boehmke (2005) by examining how direct democracy may affect the behavior of interest groups through the opportunities the institution creates.

Regarding why groups use direct democracy, it is expected that groups engage in these campaigns for strategic reasons. For instance, Kollman suggests groups use outside lobbying to signal support or opposition for their issue. Similarly, Gerber (1996) has found that direct democracy might be used to threaten legislatures to act in a particular fashion. Yet, others propose that direct democracy is used when attempts to lobby other venues have fallen short. I address these claims through the data presented below.

Finally, whether group activity differs between users and non-users enables us to address how institutional context may affect group behavior. Analyzing which groups are involved with direct democracy allows us to speak to arguments trying to assess how "representative" the direct democratic process is. Both Gerber (1999) and Boehmke (2005) find that on the surface, initiative users appear to be more active than non-users. This study seeks to more squarely address this relationship. It is expected that groups who are involved with direct democracy are likely to have a resource advantage over groups who are not active. Whether such an advantage exists 
speaks to a supposed participation gap among interest groups when it comes to the practice of direct democracy. Such a gap is at the heart of many arguments assessing the merits of direct democracy.

\section{Data and Methods}

Due to the nature of the research questions and the accessibility of data, I chose to survey interest groups in the states. As it would be prohibitively costly to survey groups from all 50 states, I decided to query groups from three states - California, Michigan, and South Carolina. While each of the 50 states provide for some element of direct democracy, not all states practice it the same way. Following Boehmke's lead, it is believed there may be important potential differences in the degree and extent of direct democracy usage in different contexts. Therefore, sampling from three distinct populations enables us to take advantage of the diversity found in the states. Consistent with similar studies of direct democracy (Gerber 1999; Boehmke 2005) the sample states were chosen based upon their relative usage of direct democracy. Thus, a high user of direct democracy (California), a moderate user (Michigan) and a low user (South Carolina) were chosen to help understand how institutional context might affect group behavior.

For each state, I first obtained a list of organizations registered to lobby. Each of these states require groups who lobby to register with their respective state government. ${ }^{1}$ Second, I examined the lists and eliminated the names of all organizations that were not membership organizations including corporations, government entities, think tanks, colleges and universities, and hospitals. I eliminated non-membership organizations from the population lists because many of my survey questions concerned groups' relations with their members. This culling process (along with the elimination of groups that could not be contacted due to flawed contact information) left me with a list of 511 groups in Michigan and 221 groups in South Carolina. In both of these states I surveyed all groups on the final list. Unfortunately, I did not have the financial resources to survey all of the groups on the California list. Thus, I randomly selected 350 (from a list of over 1,000) California groups to survey. I then conducted the survey. ${ }^{2}$ The surveys were circulated in two waves during the spring of 2003. Ultimately, 406 completed surveys were returned. The response rates were as follows: 38 percent from South Carolina (84 responses), 37 percent from Michigan (189 responses), and 38 percent from California (133 responses). The overall response rate was 37.8 percent. These response rates compare quite favorably with similar mail surveys.

The survey yielded responses from various group types. Trade associations (35\%) and professional associations (25\%) comprise the bulk of 
respondents. Responses were also received from citizen groups (9\%), charities $(9 \%)$, and labor unions (5\%). My attempt to purge corporations from my lists of organizations was not entirely successful. ${ }^{3}$ As a result, corporations comprised four percent of sample organizations. Twelve percent of sample groups did not fit into any of the aforementioned categories. ${ }^{4}$

Clearly, the research design has some flaws. Most important, the sampling of groups in only three states makes it difficult to generalize about groups in all 50 states. Nonetheless, given the nature of this research, the large $\mathrm{N}$, and the diversity of states and groups that I study, I believe the data provide a fair account of group behavior relative to direct democracy in the states.

\section{Findings: Direct Democracy in the States}

\section{Group Involvement with Direct Democracy}

The data reveal that a majority of sample groups do something relative to direct democracy. As expected, groups in California report greater activity than groups in Michigan and South Carolina. Certainly, the unique history of each state and the institutional barriers associated with direct democracy contribute to these differences. Because ballot contests are limited in South Carolina it is not surprising that South Carolina groups report minimal activity related to direct democracy. Nonetheless, the results suggest the flurry of academic scholarship on group involvement in direct democracy is warranted, as large numbers of groups are heavily involved in these campaigns across sample states.

Table 1 documents the usage of specific direct democratic techniques. Clearly, large numbers of groups report being active with a number of techniques relating to direct democracy. The most commonly reported activities are providing information to members on an initiative (71\%), joining a coalition on an initiative $(60 \%)$, and taking a public position on an initiative $(60 \%)$. The least common technique is making a financial contribution in a recall campaign ( $2 \%)$. In comparison with all lobbying techniques, the usage of direct democracy is certainly not a "popular" tactic (see Nownes and Freeman, 1998). However, considering the time, energy, money, institutional hurdles, and uncertainty involved in direct democracy campaigns, it is surprising to find that clear majorities of groups are active in campaigns of direct democracy.

The degree of a group's involvement varies considerably. Yet, nearly half of the sample groups have lobbied the state legislature regarding a ballot initiative and a significant number of groups reported that they had drafted a ballot initiative. Such involvement indicates that groups are more than passive observers of direct democracy. 


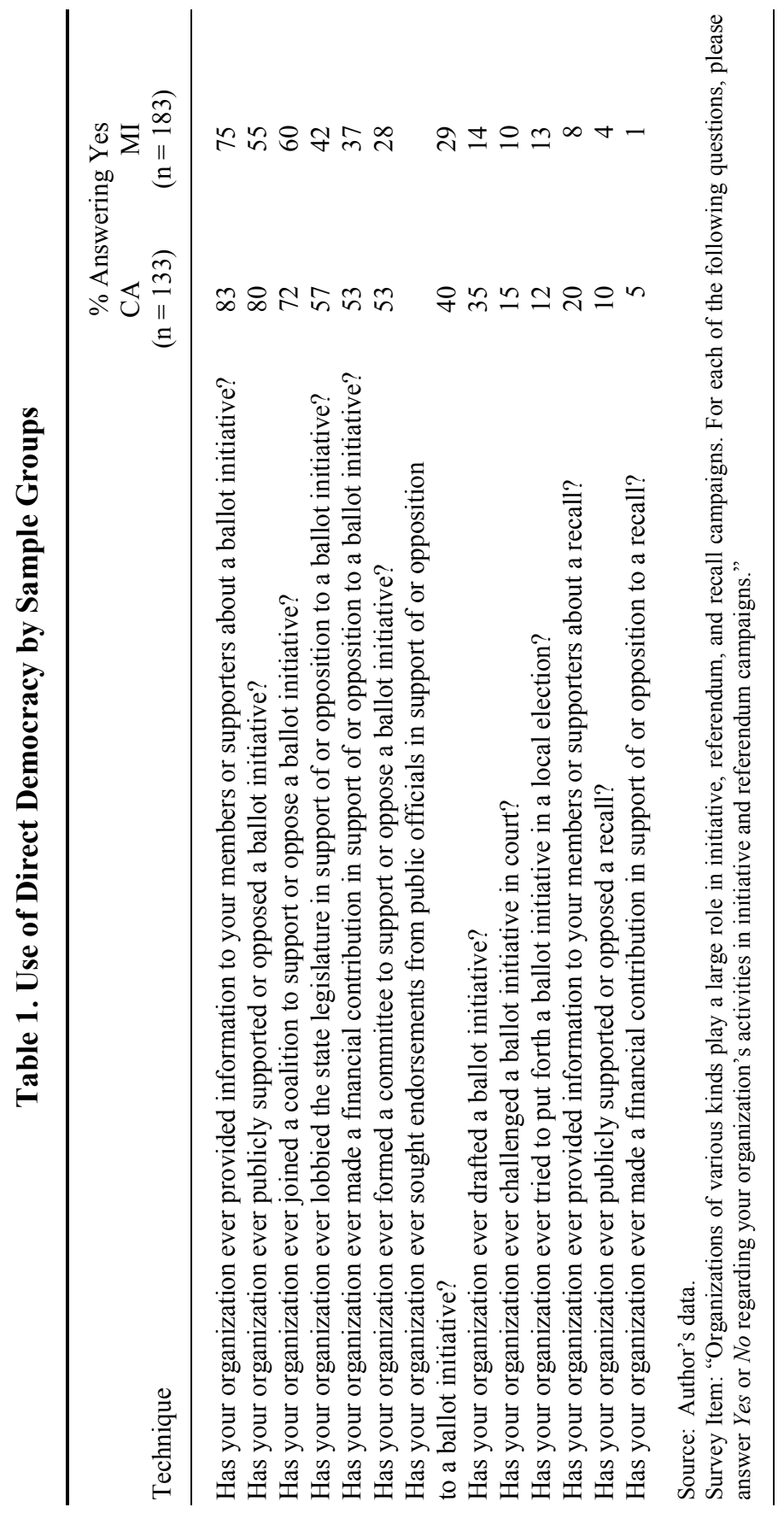


Groups in California and Michigan report very high amounts of activity relating to direct democracy. As Table 1 shows, a large majority of groups ( $85 \%$ in California and $75 \%$ in Michigan) have provided information to their members regarding a ballot initiative. Similarly, joining a coalition appears to be a strategy many groups use during ballot campaigns ( $72 \%$ in California and $60 \%$ in Michigan). Group activity in California far surpasses that of Michigan when it comes to direct democracy. Although this might be expected, the level of involvement among California groups is considerable. A majority of groups in the California sample have formed committees, made financial contributions, and lobbied the state legislature on behalf of a ballot initiative. These are not inconsequential activities. They require energy, expertise, and money. While California groups show substantial involvement with direct democracy, groups in Michigan are also quite active. Nearly a third of groups in the state have sought public endorsements from politicians for a ballot proposition, formed committees to support or oppose an initiative, and have made financial contributions to support or oppose ballot measures. Once again, these activities show a commitment by groups to partake in direct democracy campaigns. Building upon Boehmke's findings, the data presented here suggest that groups take advantage of the opportunity the existence of direct democracy provides. Thus, the initiative process enables groups to engage in many ballot-related activities (such as providing information and entering into coalitions) that they would not otherwise have.

\section{Why Groups are Involved With Direct Democracy}

As noted above, many have accused groups of using direct democracy to distort the popular will, circumvent state legislatures, or bring attention to their policy issues. Consequently, the survey queried why groups get involved with direct democracy. Table 2 shows that nearly 60 percent of sample groups say they are active in direct democracy because it allows them "to achieve long-term gains." This supports Gerber $(1999,137)$ who finds that once passed, laws made through direct democracy may produce long-term benefits and may be difficult to amend. Groups also cite the desire to affect the legislative agenda (58\%), and that campaigning through direct democracy is part of a well-balanced approach to lobbying (58\%) as reasons they participate in direct democracy.

These findings support previous work--particularly that suggesting that groups use direct democracy to affect the legislative agenda or to preempt legislative action (Gerber 1996). Cigler and Loomis (1995) have noted that groups have gone beyond doing "more of everything" and have increasingly 


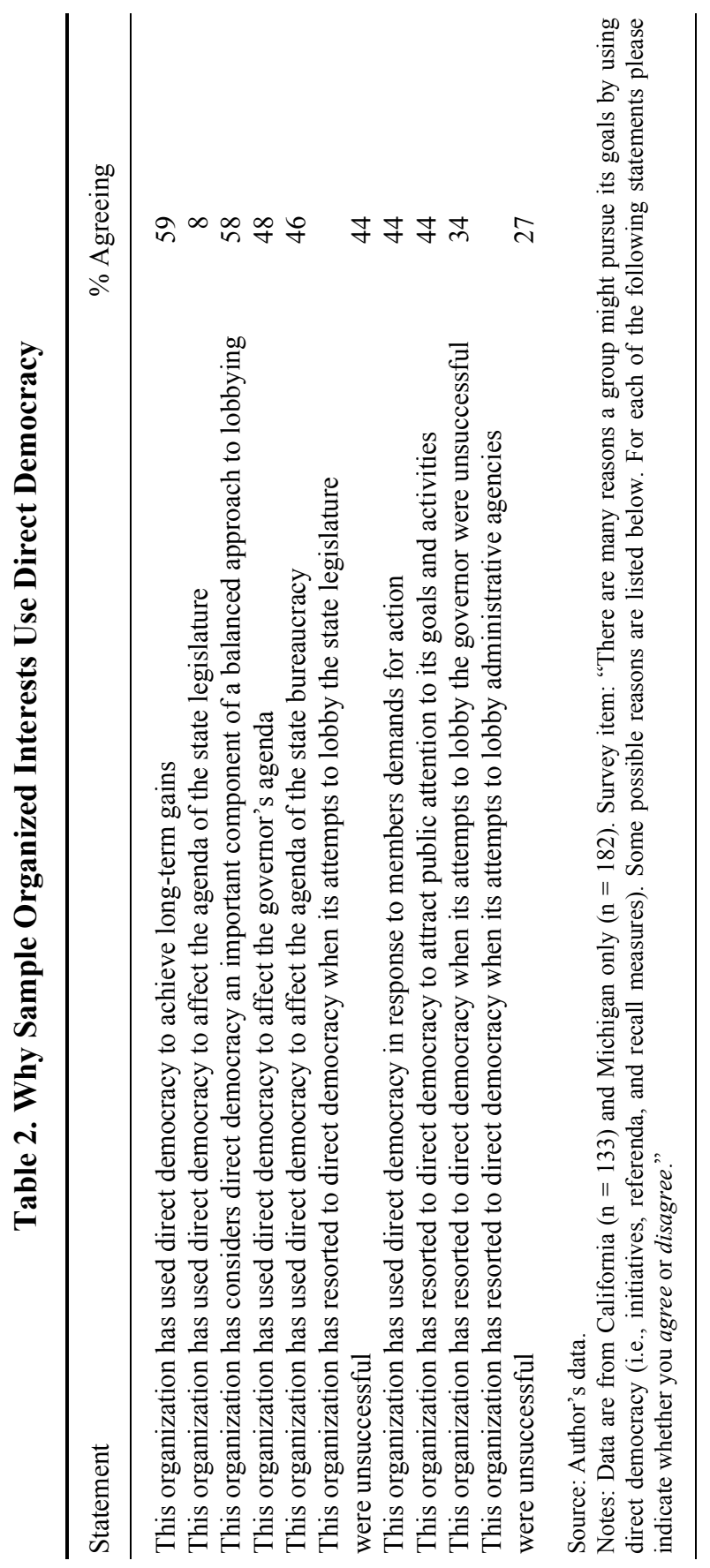


participated in advocacy and public relations tactics. That 58 percent of sample groups consider participating in direct democracy as part of a wellbalanced approach to lobbying speaks to this changing nature of interest group behavior.

Contrary to popular arguments against direct democracy, it does not appear that groups primarily look to use direct democracy when other attempts to influence government fail. Critics of direct democracy contend that it allows wealthy groups to circumvent traditional governmental institutions and appeal to the public to get what they want. When asked, nearly 60 percent of groups agree that wealthy interests dominate initiative politics, while the same percentage agree that direct democracy serves as a much needed check on the power of government. The data show some ambivalence regarding group perceptions of who is advantaged by the direct democracy process.

Table 3 tests whether wealthy interests use the initiative to circumvent the state legislature. I do this by focusing on a group's characteristics and resources. It is instructive to assess whether the type of group, the age of the group, the group's budget, or the presence of a political action committee (PAC) has an effect regarding a group's involvement with direct democracy after failed attempts to lobby the state legislature (which is the dependent variable).

Table 3 finds that citizen groups and groups that have PACs are more likely to take part in direct democracy campaigns when their efforts to lobby the legislature fall short. Although not statistically significant, Table 3 suggests that trade groups are less likely to engage in direct democracy campaigns after meeting resistance in the state legislature. In fact, if any group is emboldened to utilize the ballot, it appears that citizen groups are. Table 3 indicates a positive and statistically significant relationship to the dependent variable. Virtually no relationship is found between a group's budget and their likelihood to use direct democracy as means to shepherd their policy aims through state government channels. This finding sharply rejects the notion that wealthy groups and/or economic groups use direct democracy disproportionately. Perhaps it is a group's organizational acumen, rather than their wealth that enables them to pursue different modes of participation. In any case, the findings do not support the contention that wealthy groups use direct democracy as a means to circumvent traditional venues in an effort to achieve their goals. Instead, as Tables 2 and 3 indicate, efforts to use direct democracy after unsuccessful attempts to lobby traditional venues are not a paramount reason why groups practice direct democracy. 
Table 3. Regression Results: Who uses Direct Democracy when Lobbying the State Legislature is Unsuccessful?

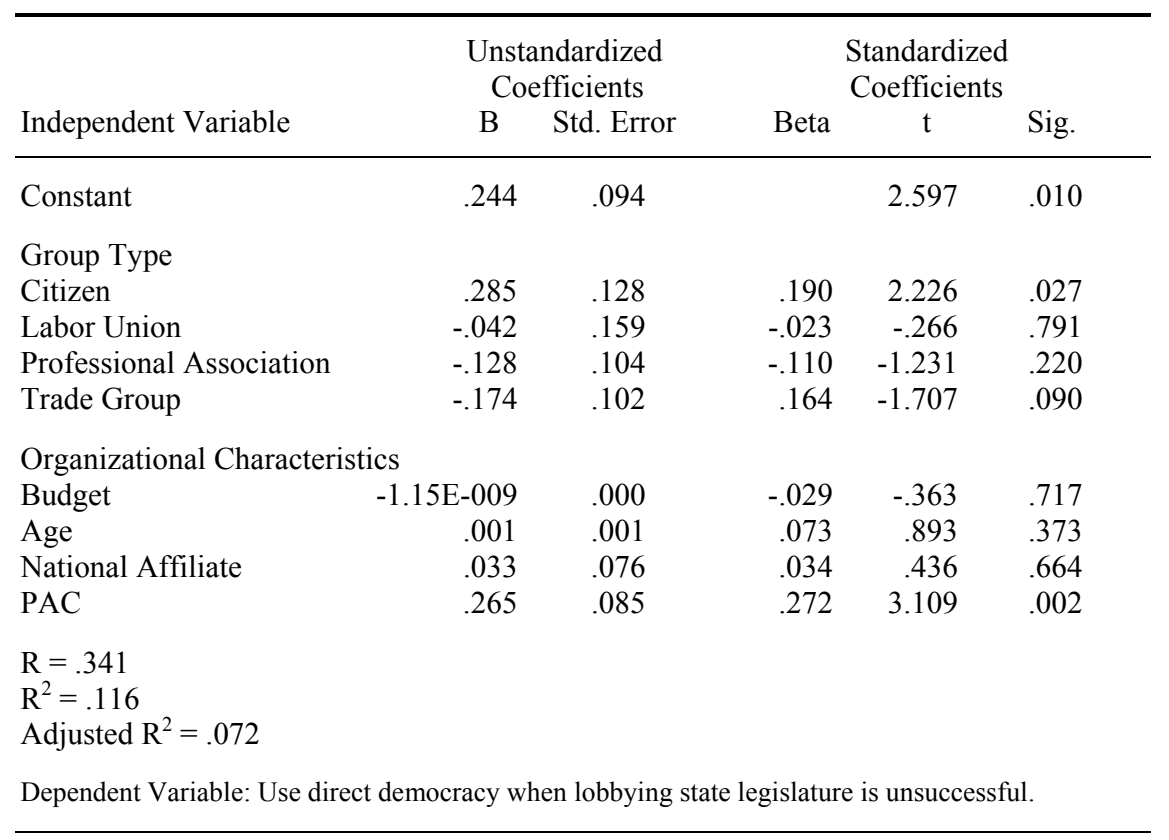

\section{Users vs. Non-users}

While many groups report that direct democracy is part of their repertoire of lobbying techniques, it is instructive to observe whether users of direct democracy differ from non-users. To address this issue, the sample was divided into "users" and "non-users." The filter variable was whether or not an organization had ever joined a coalition to support or oppose a ballot initiative. This threshold is used because the act of joining into a coalition signifies a committed effort by the group to participate in a ballot campaign. Additionally, Manweller argues that a group's coalition activity is important to the ultimate success or failure of a ballot initiative (2005). Thus, I identified 226 users and 155 non-users. The results of this exercise are summarized in Table 4.

The data indicate that users of direct democracy report greater activity across all lobbying techniques than non-users. Not surprisingly, users are much more active when it comes to outside lobbying techniques. This is consistent with previous research (Gerber 1999; Boehmke 2005). Specifically, it appears that users are noticeably more active than non-users when it 


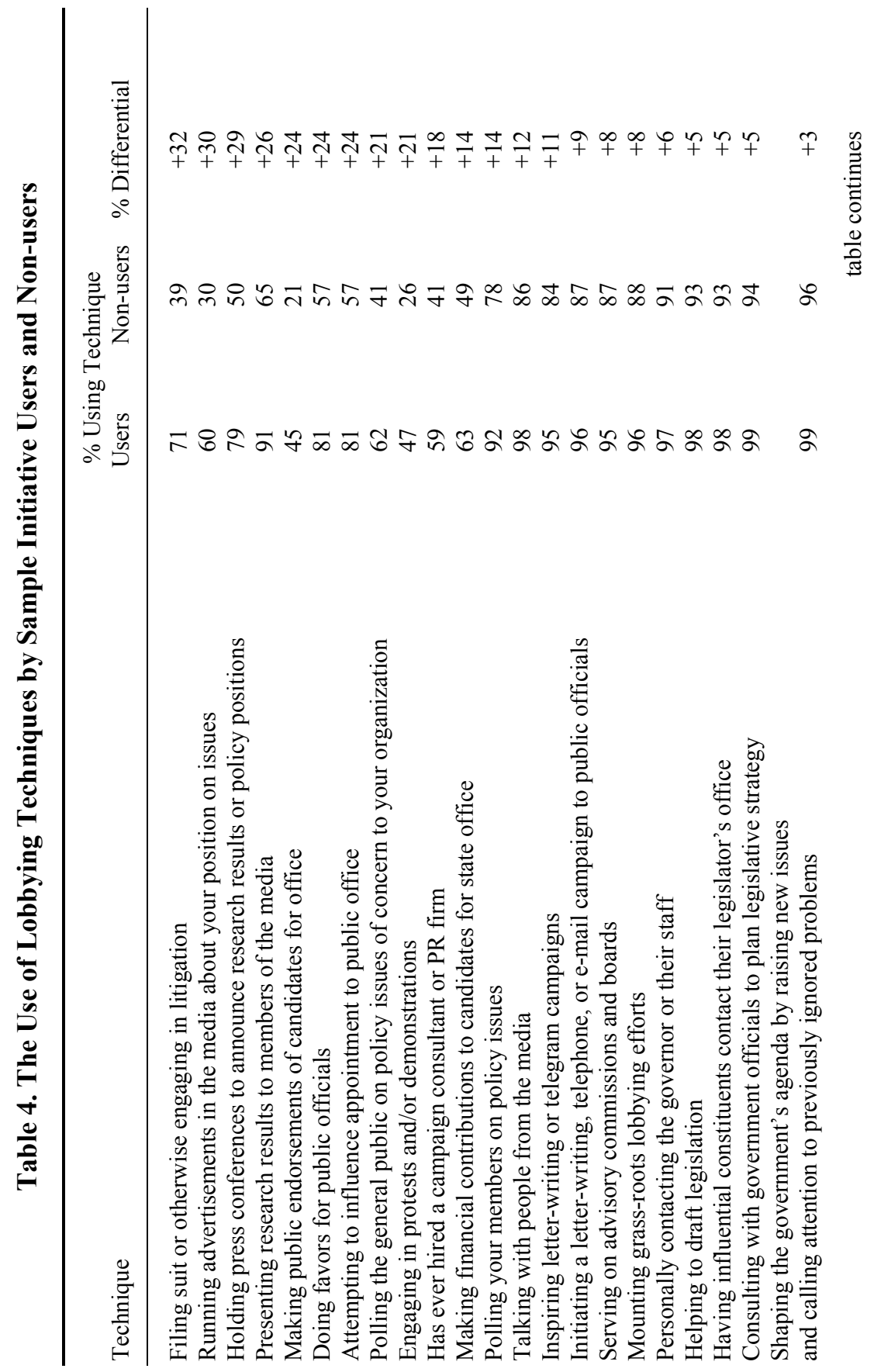




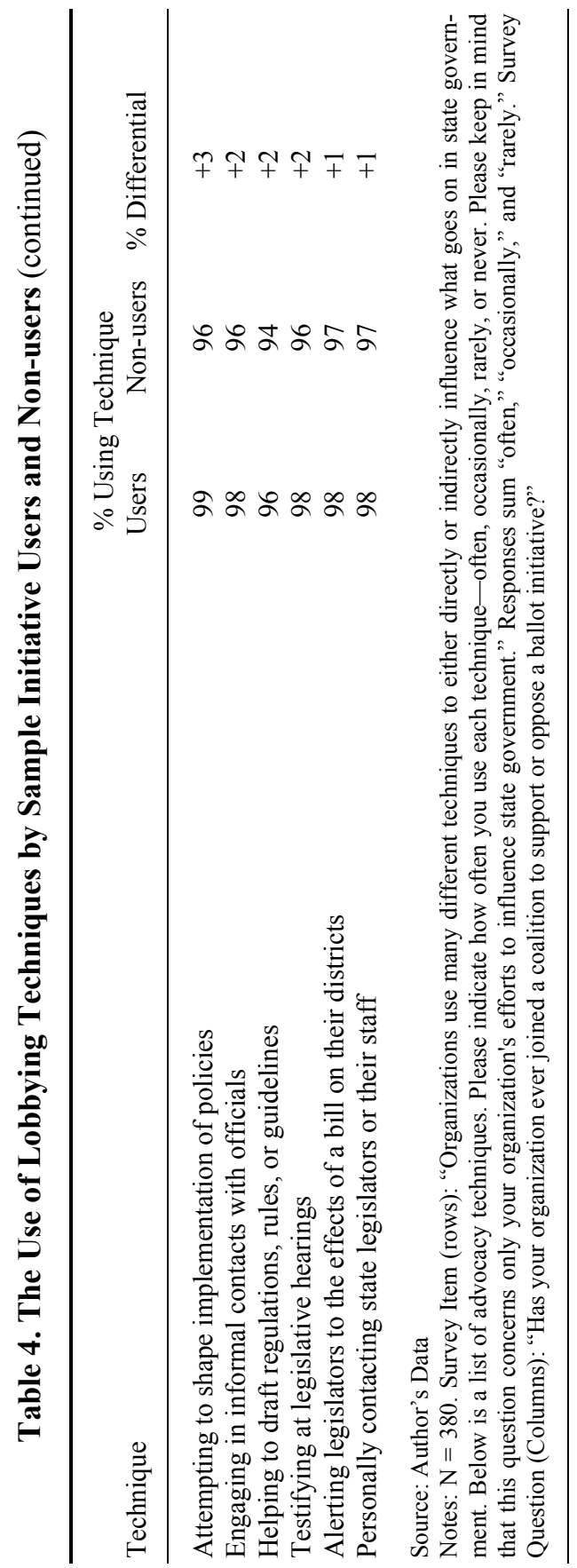


comes to filing suit, holding press conferences, making public endorsements of candidates, and running advertisements in the media. Users are also much more likely than non-users to report hiring campaign consultants, polling their members, polling the general public, and talking to the media. Most important, in virtually every instance, initiative users do more than nonusers.

This finding is relevant for a variety of reasons. First, Boehmke suggests that direct democracy as an institution affects interest group behavior. The data presented here suggest that the provision of direct democracy allows groups to utilize the process as another component of their lobbying strategies. Its existence does not go unutilized by interest groups. Instead, many are active participants in direct democracy campaigns.

Second, the data suggest that users of direct democracy must be familiar with the deployment of outside lobbying tactics. Indeed, involvement in a ballot campaign mandates the use of outside lobbying techniques. A marked difference emerges between users and non-users of direct democracy when it comes to their usage of outside lobbying activities. Non-users may be less likely to use various lobbying techniques for a number of reasons. A lack of resources, particularly a group's budget, is among the chief reasons given for the lack of participation in ballot contests. The following seeks to address the strength of such claims.

\section{The Existence of a Participation Gap?}

Whether some groups are more active in direct democracy campaigns than others is not merely an academic question. Many observers of direct democracy have voiced concerns that "big money" interests manipulate the process at their will. In short, many believe that direct democracy is dominated by the very interests it was meant to curb.

Table 5 summarizes who does what in direct democracy campaigns. Several patterns emerge from the data. First, labor unions and citizen groups are much more active than trade associations and professional associations. As Table 1 indicates, nearly one in five groups report drafting an initiative. Table 5 illustrates that labor unions and citizen groups $(45 \%$ and $34 \%$, respectively) account for almost all of the groups that do this. What really stands out in Table 5 is the hyperactivity of labor unions in direct democracy campaigns. In fact, every single labor union in the sample reported publicly supporting or opposing an initiative, providing information to their members or supporters relative to a ballot initiative, and joining a coalition to support or oppose a ballot initiative. The survey suggests that labor unions use virtually all avenues of direct democracy available to them. For example, 65 percent of labor unions report challenging a ballot initiative in court, 
which is almost unheard of for other types of groups. Moreover, unions are twice as likely to lobby the state legislature relative to a ballot proposition as are citizen groups, which are the second biggest users of direct democracy. Finally, a majority of labor unions have attempted to put forth a ballot initiative at the local level. Again, very few other types of groups report doing this. The findings presented here suggest that much of the activity Gerber attributed to citizen groups in her study may have been inflated by her collapsing of labor unions with citizen groups.

Moving beyond the descriptive data, a series of multivariate models were developed to further understand which types of groups use direct democracy. Table 6 examines those groups who joined a coalition in support or opposition to an initiative as the dependent variable. Once again, joining a coalition represents a serious investment in a ballot campaign. Table 6 shows that once again, labor unions appear to be heavily involved with ballot campaigns. The data support Ellis's (2002) claim regarding the extensive activity of labor unions in ballot contests. Citizen groups, too, continue to show a positive and robust relationship with the usage of direct democracy. Regarding organizational characteristics, a group's age and the existence of a PAC have positive and strong relationships with a group's participation in direct democracy campaigns. Table 6 further illustrates that economic groups do not appear to be too apt to become involved in ballot campaigns. Moreover, the size of a group's budget continues to show no statistical relationship with a group's involvement with direct democracy.

To explore this further, a variable called initiative index was developed. It measures a group's level of activity relative to direct democracy by summing responses from Table 1 . Table 7 presents the results of the multivariate analysis examining a group's overall direct democracy activity. Like Table 6 , it shows that the single best predictor of the use of direct democracy techniques is whether or not the group has a PAC. A group's age also appears to be an important factor, as direct democracy use increases with age. Having a PAC may indicate a high level of organization and the ability to generate multiple strategies. Similarly, a group's age may indicate experience, which may be helpful in the understanding of institutional contexts. As ballot propositions have become a more "traditional" part of what groups do, more experienced groups have been able to keep up with these changes. Clearly, longevity is beneficial for groups that are able to achieve it. That a group's age appears to be positively related to direct democracy usage supports Boehmke's $(2005,114)$ finding that established groups are more likely to be involved in ballot contests.

The signs of the "group type" estimates are in the expected directions. The results indicate that labor unions are much more active in direct democracy than are other types of groups, while professional and trade groups are 
Direct Democracy and Organized Interests | 361

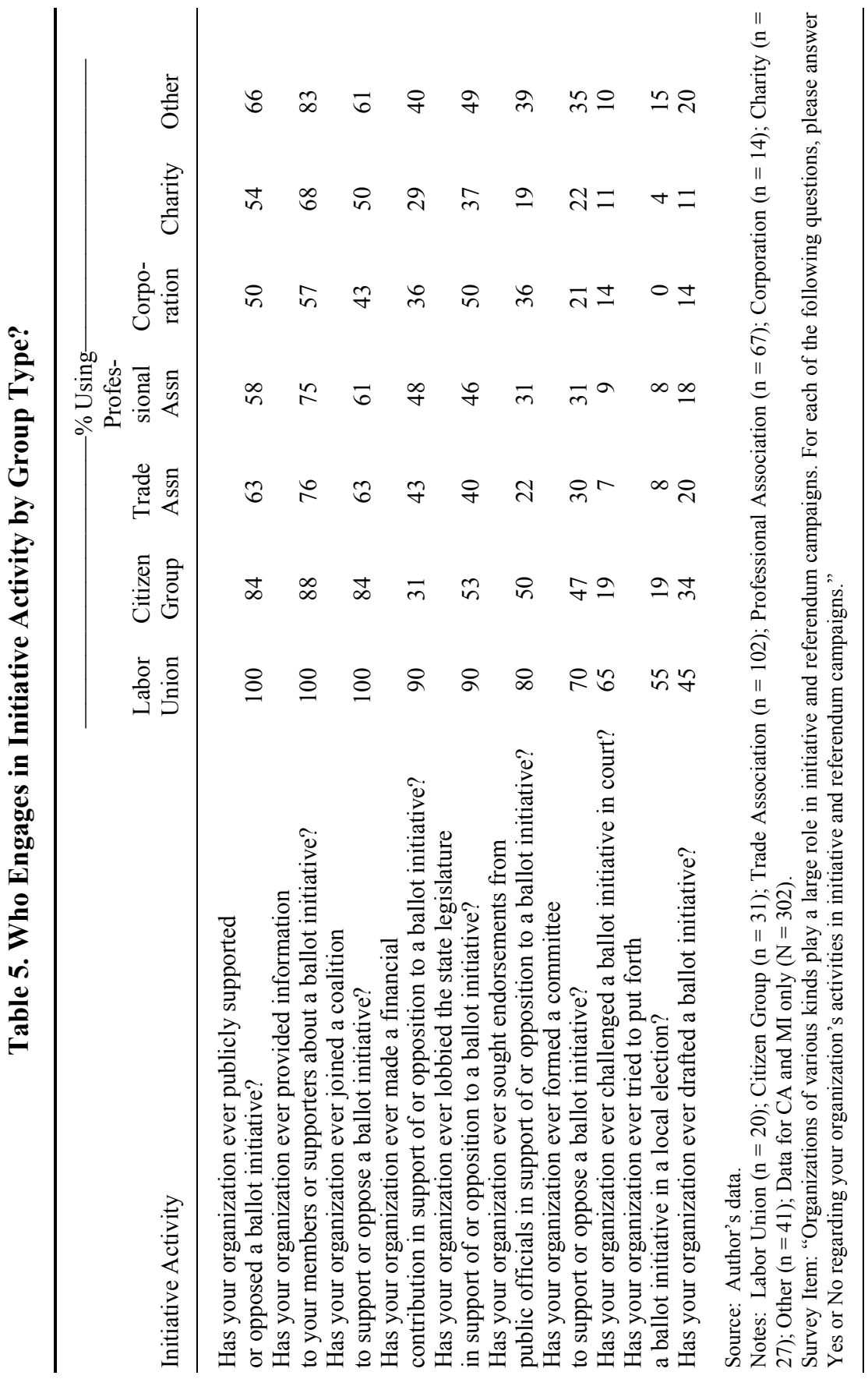


Table 6. Regression Results: Users versus Non-Users of Direct Democracy

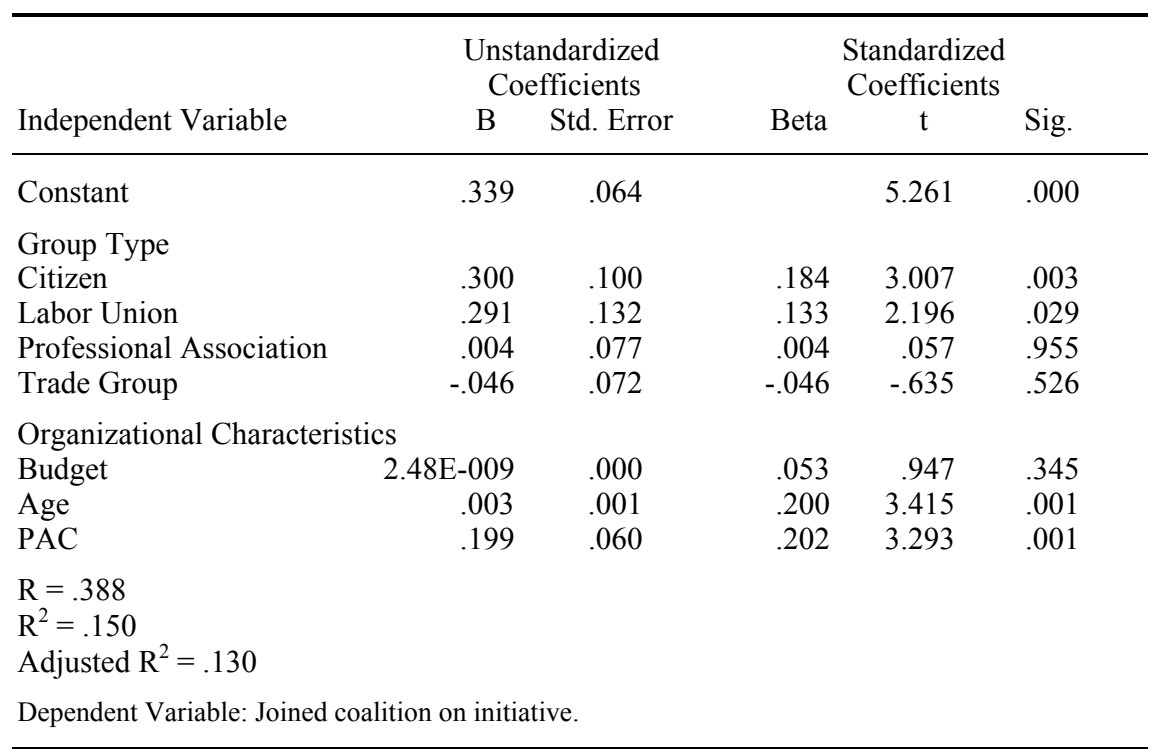

Table 7. Regression Results: Initiative Index

\begin{tabular}{|c|c|c|c|c|c|}
\hline \multirow[b]{2}{*}{ Independent Variable } & \multicolumn{2}{|c|}{$\begin{array}{l}\text { Unstandardized } \\
\text { Coefficients }\end{array}$} & \multicolumn{3}{|c|}{$\begin{array}{l}\text { Standardized } \\
\text { Coefficients }\end{array}$} \\
\hline & $\mathrm{B}$ & Std. Error & Beta & $\mathrm{t}$ & Sig. \\
\hline Constant & 2.730 & .673 & & 4.056 & .000 \\
\hline $\begin{array}{l}\text { Group Type } \\
\text { Citizen } \\
\text { Labor Union } \\
\text { Professional Association } \\
\text { Trade Group } \\
\text { Charity } \\
\text { Corporation }\end{array}$ & $\begin{array}{r}.414 \\
1.820 \\
-.837 \\
-1.280 \\
-1.363 \\
2.063\end{array}$ & $\begin{array}{r}.676 \\
.945 \\
.574 \\
.543 \\
.690 \\
2.526\end{array}$ & $\begin{array}{r}.045 \\
.136 \\
-.125 \\
-.224 \\
-.147 \\
.050\end{array}$ & $\begin{array}{r}.613 \\
1.926 \\
-1.458 \\
-2.358 \\
-1.976 \\
.817\end{array}$ & $\begin{array}{l}.541 \\
.055 \\
.146 \\
.019 \\
.049 \\
.415\end{array}$ \\
\hline $\begin{array}{l}\text { Organizational Character } \\
\text { Budget } \\
\text { Age } \\
\text { PAC } \\
\text { National Affiliate } \\
\text { Membership Group }\end{array}$ & $\begin{array}{r}\text { tics } \\
-2.18 \mathrm{E}-009 \\
.019 \\
1.782 \\
.205 \\
-.148\end{array}$ & $\begin{array}{l}.000 \\
.006 \\
.381 \\
.346 \\
.619\end{array}$ & $\begin{array}{r}-.007 \\
.220 \\
.319 \\
.037 \\
-.017\end{array}$ & $\begin{array}{r}-.106 \\
3.329 \\
4.681 \\
.591 \\
-.239\end{array}$ & $\begin{array}{l}.916 \\
.001 \\
.000 \\
.555 \\
.811\end{array}$ \\
\hline \multicolumn{6}{|l|}{$\begin{array}{l}\mathrm{R}=.526 \\
\mathrm{R}^{2}=.276 \\
\text { Adjusted } \mathrm{R}^{2}=.239\end{array}$} \\
\hline Dependent Variable: Initiati & index. & & & & \\
\hline
\end{tabular}


less active. These models simply do not indicate that direct democracy is a weapon of choice for business interests. Nonetheless, the strategic engagement of direct democracy activity by wealthy groups may explain the lack of a relationship between money and direct democracy activity in these models. Thus, the influence of well-funded interests is likely most important in specific ballot contests not accounted for through these survey data. On the whole, however, money does not appear to determine a group's ability to participate in direct democracy campaigns. In short, if a participation gap exists, it is not likely rooted in a group's budget, but in its experience, its establishment of a PAC or in specific ballot contests.

\section{Conclusion}

The data presented here shed light on the role of organized interests in direct democracy. Several findings stand out. First, a substantial majority of groups report having some involvement in direct democracy campaigns. For example, nearly three-quarters of sample groups report providing information to their members concerning an initiative, and large majorities also report having at some point joined a coalition or taken a public position on an initiative. Although scholars have previously suggested the prominence of groups in these campaigns, data presented here reveals that group involvement in direct democracy occurs across group types and among groups with varying resources. It is apparent that as ballot initiatives provide another point of access to groups, most groups take an active role in this unique venue.

Second, the survey finds that groups participate in direct democracy campaigns for several reasons. In particular, groups seek to achieve longterm gains, affect the legislature's agenda, and many see participating in direct democracy simply as part of what they do. Little is found to support the notion that groups use direct democracy as a means to accomplish their goals when they have been unsuccessful lobbying the legislature, executive, or bureaucracy. Instead, as Table 3 indicates, citizen groups and groups with PACs are most likely to engage in ballot campaigns when efforts to lobby the legislature fail. However, the strategic use of initiative politics by wealthy interest groups may be masked given the significance such interests have in specific ballot contests. Nonetheless, citizen groups and labor unions show a great deal of participation, while trade associations and professional associations show little involvement with direct democracy. Examining the quality of involvement by differing groups in ballot contests would be helpful to understand the relative power of varying types of groups. Future research should more thoroughly examine the degree of involvement, rather than simply whether particular groups participate in the process. Stratmann's 
(2006) research recognizing the strategic choices groups make in relative political environments is a promising step in that direction.

Third, the data do not reveal a participation gap between various groups. Contrary to many criticisms of direct democracy, economic groups are not disproportionately active in ballot campaigns. Instead, labor unions may be those rare groups that in Gerber's conceptualization have extensive monetary and personnel resources to actively take part in ballot campaigns. This may explain why the data show such high levels of labor union involvement in direct democracy. The data provide little evidence that a group's budget alone has a significant effect on its ability to practice direct democracy.

Finally, the data suggests that the existence of a PAC and the age of a group are strongly associated with involvement in ballot campaigns. Groups who have been involved in ballot campaigns report much greater overall lobbying activity than groups who have not taken part in these campaigns. That is, groups with greater experience lobbying in other venues and utilizing a wide array of techniques are more likely to participate in campaigns of direct democracy. This is particularly true relative to outside lobbying techniques. In both of the regression models, a group's age came up positive and statistically significant. In fact, after the existence of a PAC, a group's age appears to be the most predictive factor as to whether a group participates in ballot campaigns or not. Moving beyond the "easy" target of money spent in ballot campaigns to other organizational resources should help us gain greater insight as to who is likely to be at the forefront of ballot contests. Scholars should continue to investigate the relationship between institutions (specifically the existence of direct democracy) and organized interests in an effort to more fully understand group behavior.

\section{NOTES}

${ }^{1}$ In California lobby registration lists are available from the Secretary of State's Political Reform Division. In Michigan lobby registration lists are available from the Michigan Department of State. In South Carolina lobby registration lists are available from the South Carolina State Ethics Commission.

2Surveys were addressed to the "Executive Director/President" of each organization.

${ }^{3}$ Several corporations had names that obscured the true nature of their operations.

${ }^{4}$ Examples of "miscellaneous" group types include associations of governments (municipal leagues, etc.), coalitions (e.g., labor-industry groups), churches, and church organizations. 


\section{REFERENCES}

Baumgartner, Frank, and Beth Leech. 1998. Basic Interests: The Importance of Groups in Politics and in Political Science. Princeton, NJ: Princeton University Press.

Boehmke, Frederick. 2002. The Effect of Direct Democracy on the Size and Diversity of State Interest Group Populations. Journal of Politics 64:827-844.

Boehmke, Frederick. 2005. The Indirect Effect of Direct Legislation: How Institutions Shape Interest Group Systems. Columbus: Ohio State University Press.

Bowler, Shaun, and Todd Donovan. 1998. Demanding Choices: Opinion and Voting in Direct Democracy. Ann Arbor: University of Michigan Press.

Bowler, Shaun, and Todd Donovan. 2002. Democracy, Institutions and Attitudes about Citizen Influence on Government. British Journal of Political Science 32:371-390.

Bowler, Shaun, Todd Donovan, and Caroline Tolbert. 1998. Citizens as Legislators: Direct Democracy in the United States. Columbus: Ohio State University Press.

Broder, David. 2000. Democracy Derailed: Initiative Campaigns and the Power of Money. New York: Harcourt Press.

Cigler, Allan, and Burdette Loomis. 1995. Interest Group Politics, 4th ed. Washington, DC: Congressional Quarterly Press.

Ernst, Howard. 2002. The Historical Role of Narrow-Material Interests in Initiative Politics. In Dangerous Democracy?: The Battle over Ballot Initiatives in America. New York: Rowman and Littlefield Publishers.

Ellis, Richard. 2002. Democratic Delusions: The Initiative Process in America. Lawrence: University Press of Kansas.

Gerber, Elisabeth R. 1996. Legislative Response to the Threat of Popular Initiatives. American Journal of Political Science 40:99-128.

Gerber, Elisabeth R. 1999. The Populist Paradox: Interest Group Influence and the Promise of Direct Legislation. Princeton, NJ: Princeton University Press.

Kollman, Ken. 1998. Outside Lobbying: Public Opinion and Interest Group Strategies. Princeton, NJ: Princeton University Press.

Magelby, David. 1984. Direct Legislation: Voting on Ballot Propositions in the United States. Baltimore, MD: Johns Hopkins University Press.

Manweller, Matthew. 2005. Coalition Building in Direct Democracy Campaigns. American Politics Research 33:246-282.

Nownes, Anthony, and Patricia Freeman. 1998. Interest Group Activity in the States. Journal of Politics 93:86-112.

Schlozman, Kay, and John Tierney. 1986. More of the Same: Washington Pressure Group Activity in a Decade of Change. Journal of Politics 45:351-375.

Schrag, Peter. 1998. Paradise Lost: California's Experience, America's Future. New York: The New Press.

Smith, Daniel, and Caroline Tolbert. 2001. The Initiative to Party: Partisanship and Ballot Initiatives in California. Party Politics 7:739-757.

Stratmann, Thomas. 2006. Is Spending More Potent For or Against a Proposition? Evidence from Ballot Measures. American Journal of Political Science 50:788-801.

Tolbert, Caroline, John Grummel, and Daniel Smith. 2001. The Effects of Ballot Initiatives on Voter Turnout in the American States. American Politics Research 29:625648. 
